\title{
Evaluation of Roche Cobas Taqman Quantitative HIV-I RNA PCR against other HIV-I commercial viral load tests to examine potential under-quantification X Couto-Parada ${ }^{1}$, A Lee ${ }^{1}$, I Ushiro-Lumb ${ }^{1}$, J Anderson ${ }^{2}$, G Baily 3 , S Limb ${ }^{4}$, H Noble $^{4}$, C Orkin ${ }^{3}$, I Reeves ${ }^{2}$, A Oliver ${ }^{1}$ and D Clark*1
}

Address: ${ }^{1}$ Department of Virology, Barts and The London NHS Trust, London, UK, ${ }^{2}$ Department of Sexual Health, Homerton University Hospital NHS Foundation Trust, London, UK, ${ }^{3}$ Infection and Immunity, Barts and The London NHS Trust, London, UK and ${ }^{4}$ The Greenway Centre, Newham University Hospital NHS Trust, London, UK

* Corresponding author

from Ninth International Congress on Drug Therapy in HIV Infection

Glasgow, UK. 9-13 November 2008

Published: 10 November 2008

Journal of the International AIDS Society 2008, I I (Suppl I):P203 doi:I0.I I86/I758-2652-I I-SI-P203

This abstract is available from: http://www.jiasociety.org/content/I I/SI/P203

(c) 2008 Couto-Parada et al; licensee BioMed Central Ltd.

\section{Background}

HIV-1 RNA quantification underpins the monitoring of virological response to antiviral therapy, achievement of viral suppression and early identification of viral escape. Most laboratories use commercial HIV-1 RNA viral load tests and the genetic diversity of HIV-1 requires that these are applicable across all subtypes. We introduced the Roche Cobas Ampliprep/Cobas Taqman (CAP/CTM) Real Time Quantitative HIV-1 RNA PCR into diagnostic service after conducting a favourable comparative evaluation of 191 samples with the Roche Cobas Amplicor v1.5 PCR assay [1]. However, concerns were raised when in subsequent routine use we identified 10 patients where there was significant under-quantification (details will be presented, five subtyped all non-B). A separate study reported that Roche CTM was under-quantifying a significant number of samples across a range of subtypes compared to Amplicor [2]. We have undertaken a larger evaluation of CAP/CTM versus Roche Amplicor and have included evaluation of a subset against the Abbott quantitative HIV-1 RNA real-time PCR test.

\section{Methods}

Blood samples were obtained from three HIV clinics in north-east London for viral load testing. HIV subtype was obtained either by HIV resistance testing or PCR and sequence analysis of env and gag regions.

\section{Summary of results}

435 plasma samples from 428 patients were tested by both the CAP/CTM and Amplicor HIV-1 tests. Abbott HIV-1 real-time PCR was used to determine viral loads in 93 samples. HIV subtype was obtained for 293 samples: $67 \%$ were non- $\mathrm{B}$, reflecting the diverse demographics of the HIV-infected population in east London. There was a good correlation $\left(\mathrm{R}^{2}=0.81\right)$ between the CAP/CTM and Amplicor, although this correlation was poorer with CAP/ CTM HIV-1 RNA loads $<1000$ copies/ml. There was no apparent difference in the correlation between CAP/CTM and Amplicor for subtype $B$ and non-B viruses. We identified one patient with significant under-quantification (CAP/CTM undetectable compared to Roche Amplicor and Abbott real-time PCR values of 2.99 and $2.53 \log _{10} /$ $\mathrm{ml}$, respectively, subtype CRF13_cpx).

\section{Conclusion}

Our extended evaluation did not find the significant levels of under-quantification reported previously [2], although we did identify a further individual where the present $\mathrm{CAP} / \mathrm{CTM}$ test is unsuitable for virological monitoring. This frequency of significant under-quantification is consistent with our findings in routine diagnostic service and clinicians should remain alert to the possibility of underquantification with this test. 


\section{References}

I. Oliver T, et al.: / Clin Microbiol 2007, 45:3616-36 I9.

2. Damond F, et al.: J Clin Microbiol 2007, 45:3436-3438.

Publish with Bio Med Central and every scientist can read your work free of charge

"BioMed Central will be the most significant development for disseminating the results of biomedical research in our lifetime." Sir Paul Nurse, Cancer Research UK

Your research papers will be:

- available free of charge to the entire biomedical community

- peer reviewed and published immediately upon acceptance

- cited in PubMed and archived on PubMed Central

- yours - you keep the copyright

Submit your manuscript here:

http://www.biomedcentral.com/info/publishing_adv.asp 